\title{
Pengaruh Minyak Zaitun dan Olahraga Terhadap Kadar Trigliserida Tikus Wistar Diet Tinggi Lemak
}

\author{
Muhammad Arfan Billah Simatupang ${ }^{1 *}$, Hendra Sutysna ${ }^{2}$ \\ 1) Program Studi Kedokteran, Fakultas Kedokteran, Universitas Muhammadiyah Sumatera Utara \\ 2) Departemen Anatomi, Fakultas Kedokteran, Universitas Muhammadiyah Sumatera Utara \\ *arfansimatupang27@gmail.com
}

\begin{abstract}
Background: Triglycerides are a component of lipids used in the body to provide energy for various metabolic processes. In dyslipidemia lipid lipids occur which are marked by an increase or decrease in plasma lipids. Olive oil (extra virgine olive oil) and moderate concentration of exercise can reduce blood fat levels through the antioxidant content and lipolysis effect of each. Purposes: Knowing the effect of olive oil (extra virgine olive oil) and moderate intensity exercise on triglyceride levels in male Wistar strain rats (Rattus novergicus L.) fed a high-fat diet. Methods: This research is true experimental pretest and posttest with control group design. The study was divided into 4 groups namely K (high fat diet), P1 (high fat diet + olive oil), P2 (high fat diet + moderate intensity exercise), P3 (high fat diet + olive oil \& moderate intensity exercise) and viewed triglyceride levels from each group. Result: The average triglyceride levels of the P3 group before and after the intervention were $112.85 \mathrm{mg} /$ $d l-97.14 \mathrm{mg} / \mathrm{dl}$. Significance test results $p=0.313$ ( $p>0.05)$. Conclussion: there was no significant difference in the triglyceride levels of strain male rats.
\end{abstract}

Keywords: Dyslipidemia, triglycerides, extra virgin olive oil, moderate intensity exercise.

\begin{abstract}
ABSTRAK
Latar belakang: Trigliserida merupakan salah satu komponen lipid yang digunakan dalam tubuh untuk menyediakan energi untuk berbagai proses metabolik. Pada dislipidemia terjadi kelainan metabolisme lipid yang ditandai dengan peningkatan maupun penurunan fraksi lipid dalam plasma. Minyak zaitun (extra virgine olive oil) dan olahraga intensitas sedang dapat menurunkan kadar lipid di dalam darah melalui kandungan antioksidan dan efek lipolisis dari masing-masing. Tujuan: Mengetahui pengaruh minyak zaitun (extra virgine olive oil) dan olahraga intensitas sedang terhadap kadar trigliserida pada tikus jantan galur wistar (Rattus novergicus $L$.) yang diberi diet tinggi lemak. Metode: Penelitian ini adalah true experimental pretest dan posttest with control group design. Penelitian dibagi 4 kelompok yaitu K (diet tinggi lemak), P1 (diet tinggi lemak + minyak zaitun), P2 (diet tinggi lemak + olahraga intensitas sedang), P3 (diet tinggi lemak + minyak zaitun \& olahraga intensitas sedang) dan dilihat kadar trigliserida dari tiap kelompok. Hasil: Rata-rata kadar trigliserida kelompok P3 sebelum dan sesudah intervensi adalah 112,85 mg/dl - 97,14 mg/dl. Hasil uji kemaknaan $\mathrm{p}=0,313$ ( $\mathrm{p}>0,05)$. Kesimpulan: Terdapat perbedaan yang tidak bermakna pada kadar trigliserida tikus jantan galur wistar.
\end{abstract}

Kata kunci: Dislipidemia, trigliserida, minyak zaitun ekstra virgin, olahraga intensitas sedang. 


\section{PENDAHULUAN}

Insidensi dan prevalensi peningkatan kolesterol semakin hari semakin meningkat. Berbagai macam penyakit kardiovaskular yang ditimbulkan akibat peningkatan kolesterol diantaranya menjadi penyebab angka kematian tertinggi di dunia. Data dari World Health Organzation (WHO) tahun 2019 memperlihatkan penyakit jantung koroner dan stroke menempati urutan nomer satu dan lima masing-masing, menjadi penyebab kematian utama di dunia (1). Data yang diperoleh dari Kementerian kesehatan Indonesia menampatkan penyakit jantung koroner menjadi penyebab pertama kematian di Indonesia, dan stroke diurutan kelima (2).

Penelitian sebelumnya menemukan faktor-faktor yang dapat menimbulkan kenaikan kadar kolesterol di dalam darah, diantaranya adalah jenis kelamin laki-laki, obesitas, hipertensi, kebiasaan merokok, kurangnya latihan fisik, asupan tinggi lemak dan karbohidrat $(3,4)$.

Berbagai Lembaga kesehatan telah membuat pedoman tatalaksana untuk kasus dislipidemia seperti National Institutes of Health (NIH) dan American Heart Association (AHA), tetapi terdapat fakta bahwa beberapa penelitian yang memperlihatkan obat-obatan golongan statin menimbulkan efek samping yang serius seperti inflamasi (dermatomiositosis/ polymyositis) dan nekrotikan miopati(5-7). Karena kekhawatiran ini, perlu dilakukannya upaya yang meningkat untuk menggunakan produk alami fungsional sebagai alternatif dari perawatan modulasi lipid konvensional, yang seringkali lebih dapat diterima oleh pasien.

Minyak Zaitun dapat menjadi salah satu fitofarmaka dengan dilakukannya berbagai penelitian experimental terhadap hewan coba ataupun manusia langsung. Alasannya adalah adanya polifenol yang terkandung dalam minyak zaitun bertanggung jawab untuk menghambat kerusakan oksidatif lipoprotein dan mempromosikan transportasi balik kolesterol melalui jalur ABCA1 (ATP-binding cassette transporter Al) sehinggamemberikan perlindungan terhadap berbagai penyakit seperti kanker, aterosklerosis, dan CVD, termasuk yang melibatkan sistem saraf pusat $(8,9)$.

Perilaku hidup sehat yang lainnya seperti olahraga aerobik diharapkan mampu menjadi kombinasi dengan minyak zaitun untuk menurunkan kadar trigliserida dalam darah.

American College of Sports Medicine (ACSM) mendefenisikan latihan aerobik sebagai aktivitas apa pun yang memakai kelompok otot besar, mampu dipertahankan dan bersifat ritmis. Contoh olahraga aerobik termasuk bersepeda, menari, hiking, jogging, berenang, berjalan, dan yang semisalnya. Pada penelitian sebelumnya dilaporkan bahwa terdapat penurunan kadar trigliserida secara signifikan pada tikus terlatih setelah 8 minggu menjalankan program treadmill $(10,11)$.

\section{METODE}

Rancangan penelitian yang digunakan adalah eksperimen sungguhan (true experiment design) dengan prestest dan posttest dengan kelompok kontrol (Prestest and posttest with control group) dengan randomisasi sederhana.

Populasi penelitian ini adalah hewan percobaan tikus jantan galur wistar (Rattus novergicus L.) sehat yang berumur 10-12 minggu dengan berat 200-300 gram, diperoleh dari Unit Pemeliharaan Hewan Laboratorium (UPHL) Fakultas Kedokteran Universitas Muhammadiyah Sumatera Utara Medan. Jumlah kelompok terdiri dari 4 kelompok. Penentuan besar sampel ditentukan dengan rumus Federer sebagai berikut:

$$
\begin{gathered}
\{(t-1)(n-1)\}>15 \\
\{(4-1)(n-1)\} \geq 15 \\
3(n-1) \geq 15 \\
3 n-3 \geq 15 \\
3 n \geq 18 \\
n \geq 6
\end{gathered}
$$

Keterangan:

$\mathrm{t}=$ jumlah kelompok

$\mathrm{n}=$ jumlah sampel 
Berdasarkan hasil perhitungan tersebut jumlah sampel pada setiap kelompok nya yaitu 6 ekor tikus, sehingga total keseleruhan sampel minimal 24 ekor tikus untuk 4 kelompok yang dipilih dengan teknik randomisasi (acak) sederhana. 2 ekor tikus ditambah disetiap kelompok sebagai cadangan.

Sampel dikelompokkan atas 4 kelompok, yaitu kelompok kontrol $(\mathrm{K})$ hanya diberi diet tinggi lemak, perlakuan satu $(\mathrm{P} 1)$ diberi diet tinggi lemak dan minyak zaitun, perlakuan dua (P2) diberi diet tinggi lemak dan olahraga intensitas sedang, perlakuan tiga (P3) diberi diet tinggi lemak, minyak zaitun, dan olahraga intensitas sedang.

Keempat kelompok tersebut diadaptasikan selama 7 hari, dengan diberi makanan standar dan air minum setiap hari secara ad libitium. Pada hari kedelapan dilakukan pemberian diet tinggi lemak dari kuning telur ayam pada semua kelompok selama 14 hari per oral dengan dosis 6,25 gr/kgBB/hari dan dilanjutkan pemeriksaan kadar trigliserida awal (pretest), setelah itu dilakukan intervensi minyak zaitun selama 15 hari per oral dengan dosis 0,9gr/hari/ekor serta intervensi olahraga intensitas sedang yaitu dengan latihan berenang selama 14 hari dengan dosis 1 menit 10 detik/hari dan dilakukan pengukuran kadar trigliserida kembali (post-test) (12-14).

Data yang diperoleh dianalisis dengan memakai program komputer, yaitu Statistic Product and Service Solution (SPSS) dengan uji $\mathrm{t}$ berpasangan. Data akan diuji normalitas dengan memakai uji Saphiro-Wilk. Apabila data berdistribusi normal dapat dilanjutkan dengan uji t berpasangan, sedangkan jika data tidak berdistribusi normal maka uji yang digunakan adalah uji Wilcoxon. Hasil yang diperoleh dikatakan bermakna bila nilai sigifikansi p<0,05.

Penelitian ini disetujui oleh Komisi Etik Penelitian Kesehatan Fakultas Kedokteran Universitas Muhammadiyah Sumatera Utara (UMSU) dengan Nomor Persetujuan: 354/KEPK/FKUMSU/2020.

\section{HASIL}

Tabel 1 merupakan hasil pemeriksaan pre-test dan post-test kadar trigliserida. Selanjutnya untuk lebih mempermudah melihat perbandingan kadar trigliserida, hasil nilai trigliserida tersebut dihitung nilai rata-rata berdasarkan kelompok. Kemudian setelah didapatkan hasil rata-rata, nilai tersebut dibandingkan. Berikut disajikan dalam bentuk tabel dan gambar nilai rata-rata kadar trigliserida pada keempat kelompok.

Tabel 1. Hasil Pemeriksaan kadar trigliserida

\begin{tabular}{|c|c|c|}
\hline Kode Sampel & Pre-Test & Post-Test \\
\hline $\mathrm{K}(1)$ & 74 & 101 \\
\hline $\mathrm{K}(2)$ & 75 & 96 \\
\hline $\mathrm{K}(3)$ & 80 & 115 \\
\hline $\mathrm{K}(4)$ & 90 & 85 \\
\hline $\mathrm{K}(5)$ & 95 & 85 \\
\hline $\mathrm{K}(6)$ & 121 & 70 \\
\hline $\mathrm{K}(7)$ & 110 & 80 \\
\hline P1 (1) & 73 & 93 \\
\hline P1 (2) & 75 & 98 \\
\hline P1 (3) & 97 & 88 \\
\hline P1 (4) & 91 & 96 \\
\hline P1 (5) & 124 & 79 \\
\hline P1 (6) & 110 & 99 \\
\hline P1 (7) & 95 & - \\
\hline P2 (1) & 80 & 65 \\
\hline P2 (2) & 95 & 74 \\
\hline P2 (3) & 123 & 98 \\
\hline P2 (4) & 86 & 51 \\
\hline P2 (5) & 114 & 62 \\
\hline P2 (6) & 108 & 45 \\
\hline P2 (7) & 115 & 76 \\
\hline P2 (8) & 101 & 103 \\
\hline P3 (1) & 121 & 143 \\
\hline P3 (2) & 107 & 153 \\
\hline P3 (3) & 113 & 58 \\
\hline P3 (4) & 104 & 60 \\
\hline P3 (5) & 123 & 78 \\
\hline P3 (6) & 124 & 100 \\
\hline P3 (7) & 98 & 88 \\
\hline
\end{tabular}


Tabel 2. Rata-rata kadar trigliserida dan Standar Deviasi

\begin{tabular}{lll}
\hline \multicolumn{1}{c}{ Kelompok } & \multicolumn{1}{c}{ Pre-test } & \multicolumn{1}{c}{ Post-test } \\
\hline Kontrol $(\mathrm{K})$ & $92,14 \mathrm{mg} / \mathrm{dl} \pm 8,28$ & $90,28 \mathrm{mg} / \mathrm{dl} \pm 14,89$ \\
$\begin{array}{l}\text { Perlakuan satu } \\
\text { (P1) }\end{array}$ & $95,00 \mathrm{mg} / \mathrm{dl} \pm 19,84$ & $92,16 \mathrm{mg} / \mathrm{dl} \pm 7,57$ \\
$\begin{array}{l}\text { Perlakuan dua } \\
\text { (P2) }\end{array}$ & $102,75 \mathrm{mg} / \mathrm{dl} \pm 15,00$ & $71,75 \mathrm{mg} / \mathrm{dl} \pm 20,61$ \\
$\begin{array}{l}\text { Perlakuan tiga } \\
\text { (P3) }\end{array}$ & $112,85 \mathrm{mg} / \mathrm{dl} \pm 10,22$ & $97,14 \mathrm{mg} / \mathrm{dl} \pm 37,84$ \\
\hline
\end{tabular}

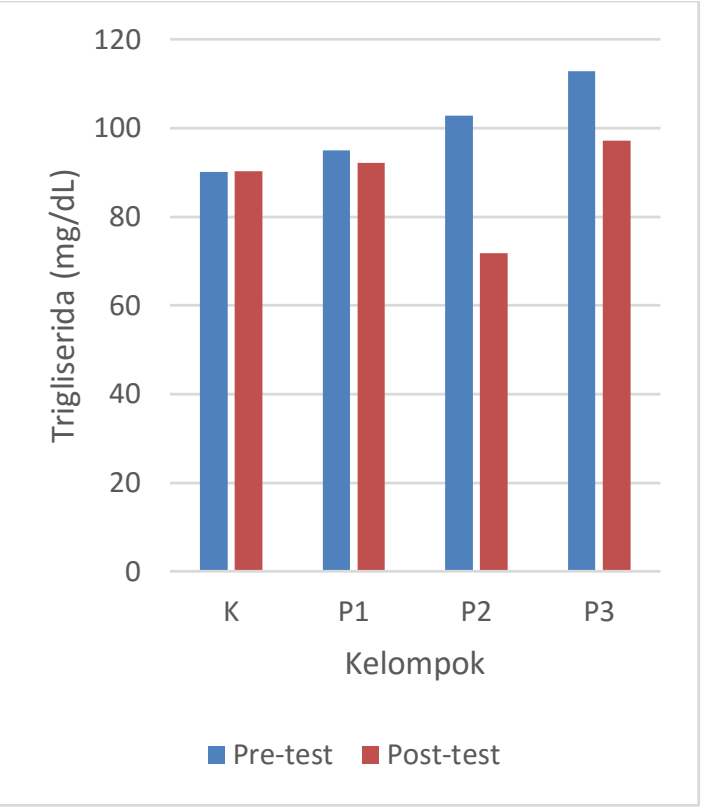

Gambar 1. Grafik nilai rata - rata kadar trigliserida pada kelompok 4

Selanjutnya dilakukan uji normalitas sebagai syarat untuk uji t berpasangan. Pada uji normalitas dengan menggunakan Saphiro- Wilk didapatkan semua kelompok berdistribusi normal. Berdasarkan data yang diperoleh dari uji t berpasangan, diketahui bahwa terdapat penurunan kadar trigliserida pada kelompok K,P1,P2,dan P3 antara sebelum diberikan intervensi minyak zaitun dan olahraga intensitas sedang (pre-test) dengan setelah diberikan intervensi minyak zaitun dan olahraga intensitas sedang (post-test) dengan nilai signifikansi terdapat pada Tabel 3.

Sehingga dari tabel 3 dapat diketahui kelompok yang terdapat perbedaan signifikan sebelum dan sesudah intervensi minyak zaitun ekstra virgin dan olahraga intensitas sedang adalah kelompok P2.

Tabel 3. Nilai signifikansi pada masingmasing kelompok

\begin{tabular}{ccc}
\hline Kelompok & Mean & Sig. (2-tailed) \\
\hline K PRE-POST & 1,85 & 0,882 \\
\hline P1 PRE-POST & 2,83 & 0,793 \\
\hline P2 PRE-POST & 31,00 & 0,004 \\
\hline P3 PRE-POST & 15,71 & 0,313
\end{tabular}

\section{PEMBAHASAN}

Hasil yang didapat dari penelitian ini memperlihatkan rata-rata kadar trigliserida pada sebelum dan sesudah intervensi minyak zaitun ekstra virgin dan olahraga intensitas sedang menunjukkan penurunan rata-rata kadar trigliserida pada semua kelompok perlakuan, tetapi yang bermakna secara statistik hanya kelompok P2 yang dimana hanya diberikan intervensi olahraga intensitas sedang saja. Manfaat dari pemberian minyak zaitun ekstra virgin adalah meningkatkan proses transportasi (Reverse cholesterol) melalui jalur ABCA 1 sehingga mencegah penumpukan lemak di pembuluh darah yang dikenal sebagai fatty streak sebagai suatu permulaan dari perjalanan penyakit aterosklerosis. Adapun manfaat dari pemberian olahraga intensitas sedang adalah dapat menurunkan lemak di dalam darah dengan cara hidrolisis jaringan lemak yang disimpan dalam bentuk triasilgliserol sebagai sumber energi bagi sel selama tubuh melakukan latihan olahraga $(8,15)$.

Hasil yang didapat pada penelitian ini berbeda dengan hasil penelitian sebelumnya oleh Kartika tahun 2012 yang menunjukkan bahwa intervensi minyak zaitun ekstra virgin dengan dosis 0,9/hari/ekor secara oral selama 21 hari dapat berpengaruh signifikan secara statistik pada kadar trigliserida tikus wistar yang diberi diet tinggi lemak (13). 
Selain itu hasil penelitian ini serupa dengan hasil penelitian sebelumnya oleh Masykur dan Martia tahun 2012 pada masingmasing penelitian menemukan bahwa terdapat peningkatan kadar HDL dan penurunan kadar LDL yang bermakna pada tikus wistar yang diberi diet tinggi lemak dengan intervensi olahraga intensitas sedang $(14,16)$.

Penelitian ini menemukan hasil bahwa terdapat penurunan bermakna pada kadar trigliserida kelompok perlakuan P2 tikus jantan galur wistar (Rattus novergicus L.) yang diberi diet tinggi lemak dengan intervensi olahraga intensitas sedang.

Perbedaan antara hasil penelitian ini dengan dengan penelitian sebelumnya mungkin dikarenakan oleh beberapa perbedaan yaitu dosis yang diberikan, lamanya waktu pemberian perlakuan dan kualitas minyak zaitun ekstra virgin yang digunakan.

\section{KESIMPULAN}

Berdasarkan dari hasil penelitian ini terdapat pengaruh yang tidak bermakna antara pemberian minyak zaitun ekstra virgin dan olahraga intensitas sedang terhadap kadar trigliserida tikus jantan galur wistar (Rattus novergicus $L$.) yang diberi diet tinggi lemak.

\section{UCAPAN TERIMAKASIH}

Saya sebagai peneliti mengucapkan terimakasih kepada semua pihak yang sudah banyak membantu selama pelaksanaan penelitian, terkhusus kepada dosen pembimbing saya bapak Hendra Sutysna dan rekan-rekan peneliti.

\section{KONFLIK KEPENTINGAN}

Selama penelitian berlangsung peneliti tidak memiliki konflik kepentingan apapun.

\section{REFERENSI}

1. WHO. World Health Statistics 2019: Monitoring Health for the SGDs. World Heal Organ. 2019;
2. Kementerian Kesehatan Republik Indonesia. Riset Kesehatan Dasar 2007. Jakarta; 2008.

3. Soleha M. Kadar Kolesterol Tinggi dan Faktor-Faktor yang Berpengaruh Terhadap Kadar Kolesterol Darah. Indones J Biotechnol Med. 2012;1(2):85-92.

4. Hidayati SN, Hadi H, Lestariana W. Hubungan Asupan Zat Gizi dan Indeks Masa Tubuh dengan Hiperlipidemia pada Murid SLTP yang Obesitas di Yogyakarta. Sari Pediatr. 2016;8(1):2531.

5. Zodda D, Giammona R, Schifilliti S. Treatment Strategy for Dyslipidemia in Cardiovascular Disease Prevention: Focus on Old and New Drugs. Pharm [Internet]. 2018;6(1):1-16. Available from:

https://www.ncbi.nlm.nih.gov/pmc/artic les/PMC5874549/pdf/pharmacy-0600010.pdf

6. Padala S, Thompson PD. Statins as a possible cause of inflammatory and necrotizing myopathies. Atherosclerosis [Internet]. 2012;222(1):15-21. Available from: https://www.atherosclerosisjournal.com/article/S00219150(11)01074-4/fulltext

7. Pinal-Fernandez I, Casal-Dominguez M, Mammen AL. Statins: pros and cons. Med Clin. 2018;150(10):398-402.

8. Berrougui H, Ikhlef S, Khalil A. Extra Virgin Olive Oil Polyphenols Promote Cholesterol Efflux and Improve HDL Functionality. Evidence-Based Complement Altern Med. 2015;1-9.

9. Gorzynik-Debicka M, Przychodzen P, Cappello F, Kuban-Jankowska A, Gammazza AM, Knap N, et al. Potential Health Benefits of Olive Oil and Plant Polyphenols. Int J Mol Sci. 2018;19(3):1-13. 
10. Patel H, Alkhawam H, Madanieh R, Shah N, Kosmas CE, Vittorio TJ. Aerobic vs Anaerobic Exercise Training Effects on the Cardiovascular System. World J Cardiol. 2017;9(2):134-8.

11. Kazeminasab F, Marandi M, Ghaedi K, Esfarjani F, Moshtaghian J. Endurance training enhances LXR $\alpha$ gene expression in Wistar male rats. Eur $\mathbf{J}$ Appl Physiol. 2013;113(9):2285-90.

12. Christina Dian A, Subando J, Kustiwinarni. Pengaruh Pemberian Angkak Terhadap Kadar Kolesterol Darah Tikus Putih (Rattus novergicus). Cermin Dunia Kedokt. 2009;168:94-5.

13. Nugraheni K. Pengaruh Pemberian Minyak Zaitun Ekstra Virgin Terhadap Profil Lipid Serum Tikus Puth (Rattus norvegicus) Strain Sprague Dawley Hiperkolesterolemia. Universitas Diponegoro; 2012.

14. Masykur MB, Nisa K, Mayang CS. Pengaruh Asupan Bubur Kacang Tanah dan Latihan Intensitas Sedang Terhadap Kadar HDL Kolesterol Tikus Putih (Rattus norvegicus) Jantan Galur Wistar yang Diberi Diet Tinggi Lemak. Universitas Lampung; 2012 p. 355-63.

15. Norton $\mathrm{K}$, Norton L, Sadgrove D. Position Statement on Physical Activity and Exercise Intensity Terminology. J Sci Med Sport. 2010;13(5):496-502.

16. Rahmawati M, Nisa K. Pengaruh Asupan Bubur Kacang Kedelai dan Latihan Intensitas Sedang terhadap Kadar LDL Kolesterol Tikus Putih (Rattus novergicus) Jantan Galur Wistar yang Diberi Diet Tinggi Lemak. Med J Lampung Univ. 2012;1(1):74-84. 